\title{
GERITEN KARO SEBAGAI PEMBENTUK IDENTITAS TEMPAT
}

\author{
Devin Defriza Harisdani ${ }^{1,}$, Dwi Lindarto ${ }^{2}$ \\ ${ }^{1,2}$ Departemen Arsitektur, Fakultas Teknik, Universitas Sumatera Utara, 20122 \\ ${ }^{\star} E$-mail : devin.defriza@usu.ac.id
}

Diterima: 9 April 2019

Direvisi: 27 Mei 2019

Disetujui: 16 Juni 2019

\begin{abstract}
ABSTRAK. Perkembangan arsitektur dunia adalah memunculkan ciri lokalitas. Saat ini peneliti Indonesia tengah menyusun kertas kerja dengan semangat pengungkapan kecerdasan Arsitektur Nusantara yang setara dengan pengetahuan arsitektur dunia. Penelitian ini bertujuan mengungkap potensi Geriten sebagai kecerdasan Arsitektur Nusantara. Pengungkapan karakter dan identitas tempat Geriten dilakukan dengan metode deskriptif kualitatif antara lain transformasi dan modifikasi geriten untuk berbagai fungsi di masa kini. Temuan menunjukkan bahwa elemen wajah arsitektur Geriten Karo meng-kini menunjukkan kecenderungan sebagai unsur pembentuk landmark (penanda tempat) melalui desain rhythm perulangan, vista, vertikalitas, ungkapan focal point. Bentuk ayo tampil sebagai pembentuk identitas Karo dalam transformasi bentuk dan proporsi. Unsur bentuk atap Geriten pantas dilestarikan dan dikuatkan sebagai unsur arsitektur pembentuk identitas tempat.
\end{abstract}

Kata kunci : Geriten Karo, Transformasi Arsitektur, Identitas tempat

\begin{abstract}
The development of world architecture is characterizing by locality aspects. Currently, Indonesian researchers propose a working paper with the spirit of the discourse about the intelligence of Arsitektur Nusantara, which is equivalent to the knowledge of world architecture. This study aims to reveal the Geriten as the intelligence of Arsitektur Nusantara. Disclosure of the Geriten's place identity and the character done with qualitative descriptive methods include Geriten transformation and modification element of architecture for a variety of functions in the present. The findings indicate that the shape of the Geriten in Karo contemporary architecture shows a tendency as a component of formation landmark through the design iteration rhythm, vista, verticality, expression of the focal point. The shape of Geriten's ayo appears as forming Karo identity in the transformation and proportion. The Geriten roof strengthened as an element of place identity.
\end{abstract}

Keywords: Geriten Karo, Architecture Transformation, Place Identity

\section{PENDAHULUAN}

Perkembangan arsitektur dunia masa kini diwarnai oleh usaha untuk memunculkan kembali kekhususan ciri lokalitas yang kemudian dilafalkan menjadi regionalisme dengan tampilan keunikan tempat beridentitas. Kehendak untuk memperlihatkan identitas setempat dan potensi olah rancang bangun yang berbeda antar tempat dianggap menjadi suatu keharusan dan populer sebagai pokok bahasan narasi maupun praksis di era abad XII. Fenomena demikian berlangsung juga di Indonesia melalui diskusi panjang atas nama Arsitektur Nusantara, suatu model penalaran arsitektur yang dibangun atas pengetahuan arsitektur (bukan antropologi atau selainnya).

Sejauh ini para penggiat Arsitektur Nusantara di Indonesia telah menghasilkan banyak kertas kerja dalam rangka mengungkap kecerdasan arsitektur daerah ditengah ironi kemusnahan artefak arsitektur daerah itu sendiri. Semangat yang melandasi adalah pemahaman bahwa pengetahuan arsitektur daerah mempunyai kecerdas-an sebagai kemampuan otak/nalar; tapi juga mempunyai ke-cerdik-an sebagai kemampuan intuisi/perasaan manusia pembuatnya.

Tuntutan pengungkapan regionalisme arsitektur daerah di Indonesia dalam upaya berarsitektur kiwari menjadi halal dilakukan penghadiran kembali segenap ungkapan dan komponen arsitektur klasik atau daerah atau tradisional guna melihatkan identitas atau jati diri bangsa (Prijotomo, 2004). Metode olah pikir yang ditawarkan antara lain dengan menempatkan arsitektur daerah sebagai rekaman pengetahuan arsitektur yang dapat digunakan untuk "membuat" arsitektur yang me-nusantara disatu pihak dan menjadikan arsitektur daerah sebagai warga arsitektur dunia di pihak yang lain. Penelitian ini ibarat pengungkapan selubung demi selubung lipatan pengetahuan arsitektur daerah yang 
akan mengkayakan khasanah pengetahuan indigenous arsitektur daerah di Indonesia sebagai materi dalam upaya mewujudkan arsitektur yang berjati diri.

Di pulau Sumatera utamanya di Sumatera Utara setidaknya terdapat tujuh etnis mengemuka yaitu Nias, Pak-Pak Dairi, Melayu, Mandailing, Toba, Simalungun dan Karo. Suku Karo tinggal di dataran tinggi 1300 $\mathrm{m}$ dpl di lereng gunung Sinabung dan Sibayak Kabupaten Tanah Karo. Masyarakat Karo sebagian masih penganut Pemena atau Pabegu selain pemeluk agama Islam atau Kristen. Masa kini permukiman Karo yang masih cukup terawat terdapat di desa Lingga Kabupaten Karo sejauh 4,5 km dari ibu kota Kabanjahe.

Suatu pemukiman rumah Karo yang disebut Kuta terdiri atas beberapa rumah Si Waluh Jabu (rumah tinggal), Sapo Page (lumbung padi), Jambur (balai berkumpul), Jambur Lesung (tempat menumbuk padi) dan Geriten (tempat tulang moyang). Eksistensi Geriten terlihat di tengah kemusnahan tipe rumah Karo (tercatat tahun 2017 desa Lingga menyisakan hanya 3 bangunan Si Waluh Jabu, Jambur Lesung dan Geriten). Arsitektur yang disebut Geriten oleh masyarakat kini hanya menunjuk kepada hiasan tugu, gerbang desa jauh dari kesan sakral sumber keteladanan nenek moyang. Khasanah kecerdasan arsitektur Karo sendiri telah banyak ditelaah dari sisi keberadaan Geriten (dalam Loebis, 2004; Schefold, R, 2014). Dengan memperhatikan kebertahanan arsitektur Geriten maka menarik untuk diungkapkan unsur yang meneguhkan Geriten sebagi suatu bentukan yang tetap dipakai dalam berbagai kreasi desain arsitektur Karo masa kini.

\section{IDENTITAS TEMPAT}

Identitas tempat dimaknai sebagai unsur yang menjadikan suatu tempat ter-identifikasi dengan baik membentuk keterikatan suatu tempat dengan person pengamat sebagai suatu place attachment. Sebagaimana diketahui framework dasar multi dimensi konsep place attachment adalah merupakan pengorganisasian tripartite antara person, proses psikologi dan dimensi place/tempat (Scannel, 2009).

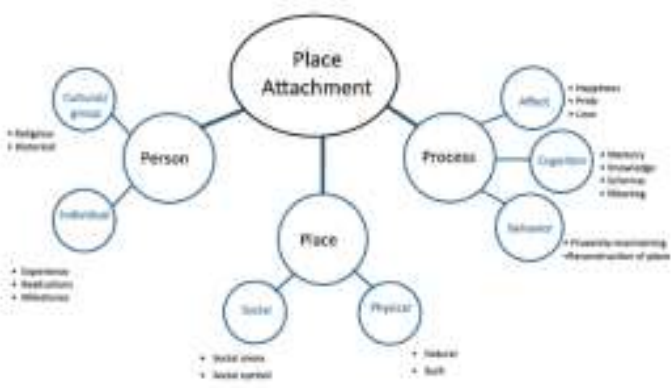

Gambar 1. Konsep Place Attachment (Scannel, 2009)

Penelitian ini difokuskan kepada kajian dimensi tempat yang berpotensi sebagai unsur pembentuk identitas yaitu bagaimanakah arsitektur (bentukan tempat) mampu tampil sebagai suatu identitas lokal menggubah keterikatan seseorang dengan tempat.

Perbincangan place attachment menunjuk pada place sebagai subyek bahasan yang diterangkan dalam berbagai tinjauan skala geografis mulai dari ruang makan di rumah, desa atau kota dan terbagi menjadi ragam tipe secara keterikatan tempat sosial dan keterikatan tempat ragawi (Riger \& Lavrakas, 1981). Kekuatan keterikatan tempat terkuat adalah suasana home (rumah) dan lingkungan tempat tinggal semasa kecil dimana suasana sosial terbentuk oleh lama tinggal lebih terpatri di benak pengamat dibanding dimensi fisik lingkungan semata (Hidalgo \& Herna'ndez, 2001).

Seseorang juga merasa adanya keterikatan dengan tempat yang memfasilitasi kegiatan sosial bersama dan grup beridentitas tertentu (kelompok lifestylish). Dalam hal ini tampilan fisik tempat yang mempertimbangkan densitas, kedekatan dan tampilan fasilitas umum sangat berpengaruh terhadap kemenjadian keterikatan terhadap tempat tersebut (Fried, 2000). Lalli (1992) menyatakan bahwa hal keterkaitan secara spasial menjadi penting bagi keterikatan terhadap tempat karena tempat menyimbolkan kondisi sosial dan identitas sosial yang berujung pada place identity. Keterikatan tempat terwujud antara lain karena adanya "distinctiveness" antar tempat atau adanya kekhasan tatanan penampilan tempat tersebut (Twigger-Ross \& Uzzell, 1996).

Keluasan unsur keterikatan terhadap tempat mencakup segenap lingkungan binaan mulai dari rumah, jalan, arsitektur, bangunan utilitas sampai lingkungan alami seperti danau, hutan, kebun, bukit, gunung dan sungai (Manzo, 
2003; Manzo, 2005). Konsep yang sejalan adalah environmental identity yang juga menekankan bahwa place attachment sangat tergantung kepada aspek fisik dan sosial suatu tempat (Clayton, 2003).

Bagaimana suatu tatanan fisik mempunyai pengaruh yang menjadikan seseorang mempunyai keterikatan suatu tempat menjadi fokus dari pengungkapan penelitian ini. Makna (symbolic meaning) suatu tatanan arsitektur menjadi mediasi bagi terbentuknya model keterikatan tempat. Stedman (2003) menyatakan bahwa seseorang tidak serta merta mempunyai keterikatan dengan suatu tempat namun pemaknaan terhadap suasana tempat tersebut dalam bentuk kegiatan atau atmosphere menjadikan segera terbentuknya keterikatan terhadap tempat tersebut.

\section{METODE PENELITIAN}

Pada tahap awal penelitian dilakukan untuk menganalisis perubahan arsitektur Geriten Karo dengan menggunakan metode kualitatif naturalistik inquiry, menarik kesimpulan penelitian secara induktif atas tema-tema temuan lapangan, mengabstraksikan realitas ke dalam konstruksi konsepsual dan menggunakan peneliti sebagai instrumen utama penelitian. Perolehan data dilakukan dengan cara observasi langsung di lapangan berupa rekaman foto objek arsitektur Geriten Karo dalam fungsinya sebagai penanda tempat. Untuk mengungkap unsur kreasi Geriten sebagai penanda / identitas tempat (place identity), digunakan metode mixedmethod dengan strategi eksplanatoris sekuensial (Creswell, 2017).

Peneliti melakukan observasi langsung terhadap atribut daya ungkit pembentuk identitas pada objek Geriten arsitektur Karo yaitu Distictiveness yang terbentuk oleh tatanan Vertikalitas, Setting, Social Occasion, Boundary, Orientation dan Rhythm di lapangan (Lindarto, 2018). Perolehan data awal dilanjutkan dengan analisis bentuk untuk menemukan karakter khas lain sebagai sebagai suatu genius loci (Schulz, 1980). Analisis demikian akan mampu menyusun tipologi bentuk arsitektur khas Karo. Selanjutnya dilakukan analisis elemen transformasi dan transformasi bentuk lanjutan diluar atribut yang sudah ada, sehingga dalam penelitian ini akan dihasilkan sebuah model transformasi arsitektur Geriten Karo (DunhamJones, 2008). Hal ini juga sejalan dengan penelitian model perubahan arsitektur vernacular (Sulistijowati, 2017). Model transformasi ini akan menjadi tipologi model perencanaan berbasis kearifan lokal (genius $\mid 0 c 1)$.

\section{HASIL DAN PEMBAHASAN}

Survey fisik dan aktivitas dilakukan pada beberapa objek di desa Lingga Karo, Kantor Bupati Kabupaten Karo, Kantor DPRD Kabupaten Karo, Simalem Resort Merek, Kota Kabanjahe dan Berastagi, Kota Medan.

Di desa Lingga terdapat gapura yang menggunakan bentuk Geriten menjadi pilihan penataan oleh Pemerintah Kabupaten Karo, dengan tujuan sebagai pembentuk citra kawasan desa wisata ini. Bentukan Geriten pada gapura ini memiliki ekspresi yang mengarah kepada kualitas landmark kawasan, dengan penggunaan unsur ketinggian / vertikalitas sebagai unsur pembentuk identitas tempat.

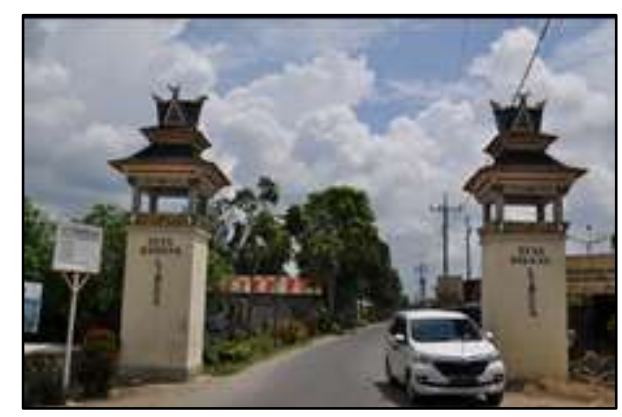

Gambar 2. Gapura Desa Lingga, Kabupaten Karo (Sumber: observasi peneliti, 2018)

Geriten di puncak gapura merupakan penanda identitas yang mempunyai kemampuan membentuk (imageability) citra district / setting sebagai suatu virtual boundary penanda teritorial desa tersebut. Gapura ini merupakan batas awal pintu masuk ke kawasan yang mempersepsi batas teritorial kawasan dengan penempatan Geriten sebagai focal point membentuk enclosure wilayah (Schulz, 1980). Gapura dengan tancapan Geriten ini merupakan ungkapan sentralitas memperkuat pembentukan virtual boundary.

Pada kawasan rumah adat Desa Lingga, terdapat sebuah Geriten-ladang, Geriten ini difungsikan sebagai bentukan 'penjagaan' dan pembentuk citra dengan kreasinya sebagai penanda jalur arah menuju rumah Si Waluh Jabu. 


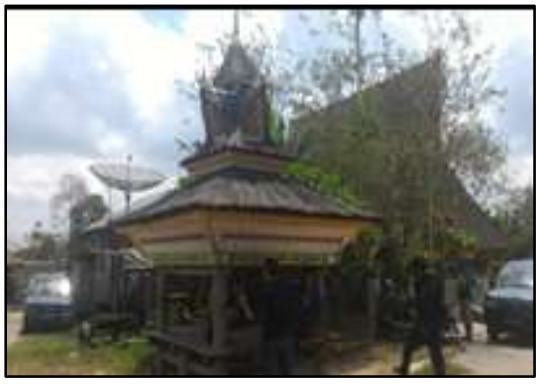

Gambar 3. Geriten ladang Desa Lingga, Kabupaten Karo (Sumber: observasi peneliti, 2018)

Elastisitas dan simplifikasi Geriten juga terjadi pada beberapa objek di Kota Kabanjahe sebagai ibukota Kabupaten Karo. Bentuk Geriten terdapat pada bagian atap dari halte dan beberapa kantor di kawasan kota ini. Pergeseran fungsi Geriten yang sakral menjadi Geriten dengan fungsi kekinian terjadi dengan mengalami penyederhanaan bentukan namun miskin makna terutama dalam pandangan masyarakat modern (Rapoport, 1969).

Pada Kantor Bupati Karo dan Kantor DPRD Kabupaten Karo, perulangan (rhythm) penggunaan bentukan Geriten dilakukan pada bagian atap. Dilengkapi pula dengan penggunaan ornamentase yang berulang dapat dikaitkan dengan potensi pembentuk landmark (Lynch, 1960) bagi Kota Kabanjahe.

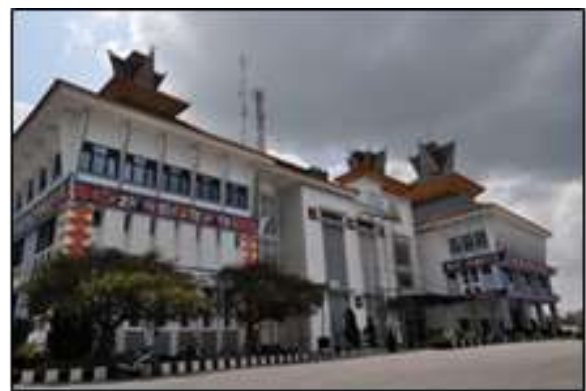

Gambar 4. Bentukan Geriten dan ornamen pada atap Kantor Bupati Kabupaten Karo (Sumber: observasi peneliti, 2018)

Elastisitas bentukan Geriten ini juga terjadi dalam fungsi sebagai penanda tempat kantor pemerintahan lainnya di Kabupaten Karo. Pada Kantor Dinas setempat terdapat penggunaan bentukan Geriten pada atap dalam orientasinya ke empat sisi, namun menggunakan bentukan atap rumah Si Waluh Jabu sebagai bentuk utama.

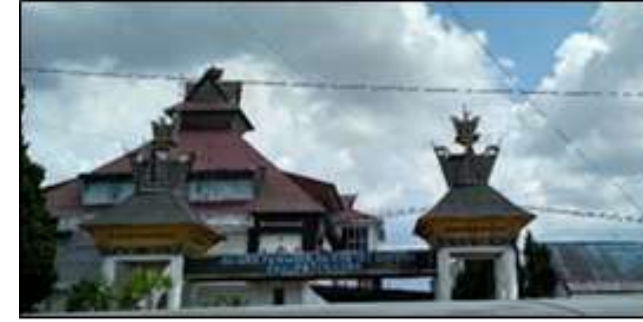

Gambar 5. Bentukan Geriten dan ornamen pada atap Kantor DPRD Kabupaten Karo (Sumber: observasi peneliti, 2018)

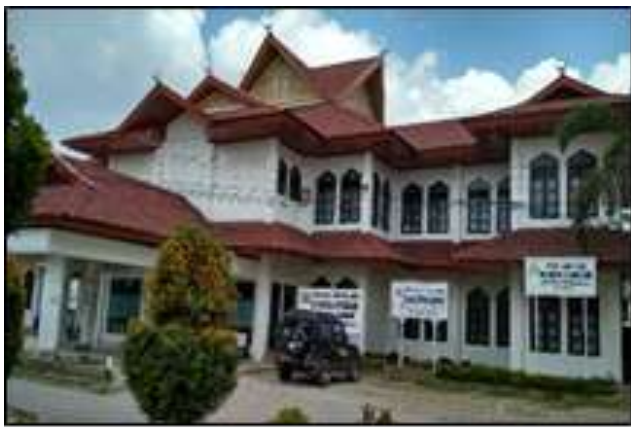

Gambar 6. Orientasi Geriten dan atap Si Waluh Jabu Kantor Dinas Kota Kabanjahe, Kabupaten Karo (Sumber: observasi peneliti, 2018)

Dalam survey ke Kantor Camat setempat, bentukan Geriten tidak terjadi pada bagian atap, namun untuk melengkapi penunjuk arah dan identitas setempat, di bangun sebuah Geriten-ladang pada area kantor.

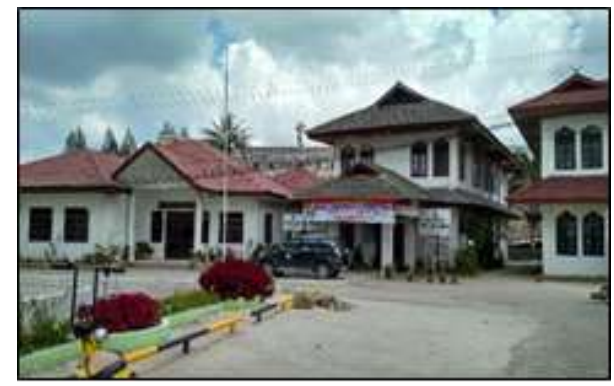

Gambar 7. Geriten ladang di Kantor Camat setempat, Kota Kabanjahe, Kabupaten Karo (Sumber: observasi peneliti, 2018) 


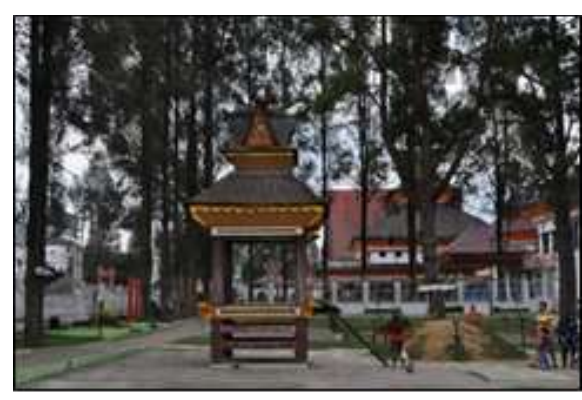

Gambar 8. Geriten di area Kantor Camat setempat, Kota Kabanjahe, Kabupaten Karo

(Sumber: observasi peneliti, 2018)

Berbagai tindakan transformasi dalam keragaman fungsi sebagai bangunan pemerintahan diatas dilakukan dalam upaya membangun distinctiveness sebagai penguat persepsi terhadap keunikan dan penandaan tempat atau objek pemerintahan, yang bersifat formil dengan distinctiveness, kebedaan objek lain pada kawasan sekitarnya. Identitas bentuk fisik arsitektur Geriten dipakai sebagai simbol pemerintahan/kekuasaan yang terjadi menjadi sebuah similarity, kesamaan untuk melegitimasikan kekuasaan (Barliana \& Cahyani, 2011).

Selain menampilkan keberagaman namun dalam penerapannya terjadi penyeragaman dari bentukan Geriten sebagai sebuah jati diri arsitektur Karo. Penggunaan bentukan Geriten pada gedung pemerintahan tidak lebih dari hanya sebuah formalitas. Kesan yang didapat dari bangunan adalah tampilan modern dengan ciri khas etnis setempat yang ditempel saja. Hal ini menandakan tidak adanya makna khusus dari penerapan arsitektur Karo tersebut melainkan hanya sebagai pembentuk identitas visual.

Penggunaan unsur vertikalitas dari bentukan Geriten juga didapati pada bangunan gereja di Kota Kabanjahe. Orientasi ke atas dan vertikalitas pada arsitektur gereja menjadi dasar dalam menempatkan identitas bentukan Geriten pada bagian gerbang masuk dan pada bagian tertinggi di bangunan gereja yang ada.
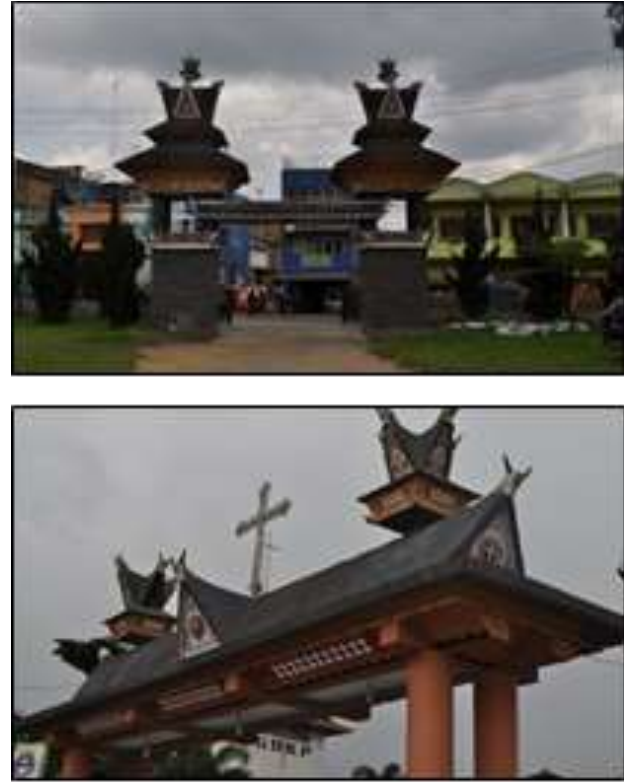

Gambar 9. Gapura gerbang Gereja setempat, Kota Kabanjahe dan Berastagi, Kabupaten Karo

(Sumber: observasi peneliti, 2018)

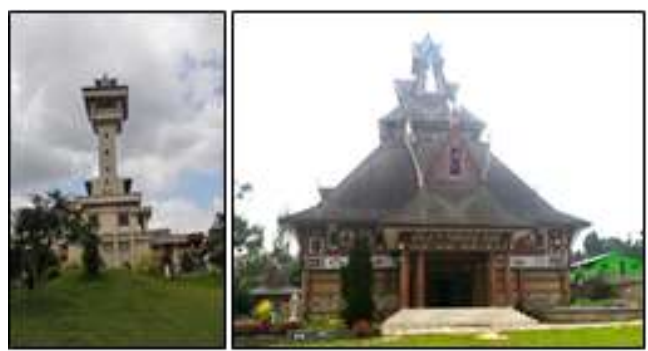

Gambar 10. Vertikalitas bentukan Geriten pada Gereja setempat, Kota Kabanjahe dan Berastagi, Kabupaten Karo (Sumber: observasi peneliti, 2018)

Keunikan dicapai dengan perulangan sebagai rhythm dari Geriten pada bagian gapura gerbang menjadi pilihan tipologi bentukan arsitektur dalam membentuk identitas tempat.

Pada kawasan perkotaan, jati diri arsitektur Karo dapat dilihat dari pembentukan identitas tempat yang menggunakan bentukan arsitektur Geriten yang terlihat dominan pada bagian atap dan gapura. Setiap gapura dilengkapi dengan tulisan yang menginformasikan fungsi bangunan tersebut. Hal ini menciptakan suatu boundary yang mampu dimengerti oleh masyarakat sebagai batasan dari kawasan gedung tersebut sekalipun tanpa pagar. Selain itu, penerapan Geriten pada gapura seakan menghadirkan kembali makna Geriten ladang sebagai tempat pengawasan dari tindak kriminalitas yang mungkin terjadi.

Penerapan bentuk atap Karo kian mengalami perkembangan dan bertransformasi. 
Simalem Resort, Geriten menjadi pembentuk identitas tempat pada kawasan tersebut. Bentukan atap Geriten diaplikasikan pada berbagai tempat, mulai dari gapura, atap hotel, gazebo, hingga pada lampu taman. Transformasi bentukan arsitektur Geriten pada setiap tempat berbeda, mulai dari transformasi material, transformasi dimensi, hingga penghilangan ornamentasi.

Meskipun atap Geriten tersebut sangat dominan diterapkan, namun tidak terkesan monoton karena adanya permainan unsur vertikalitas (ketinggian). Dimana, pada kawasan Simalem Resort ini menunjukkan sisi lain dari vertikalisasi Geriten. Ternyata untuk menghasilkan suatu vista yang menarik, selain dengan membuat ketinggian Geriten sejajar dengan bangunan utama ataupun ditinggikan di tengah-tengah ladang yang luas, dapat pula diterapkan dengan ketinggian di bawah bangunan utama serta berubah fungsi sebagai lampu taman, sebagai penambah nilai estetika sekaligus membentuk identitas taman pada kawasan tersebut.

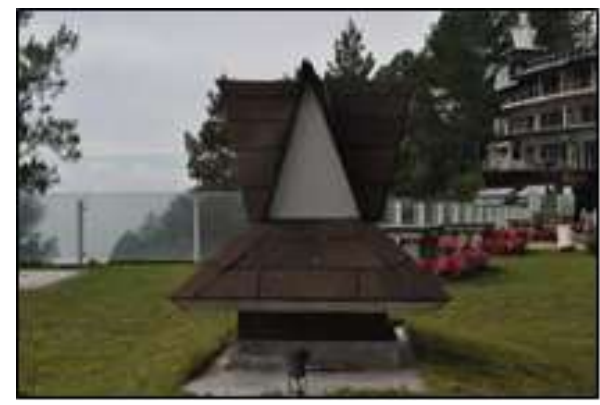

Gambar 11. Lampu taman dengan bentukan Geriten pada kawasan Simalem Resort, Kabupaten Karo (Sumber: observasi peneliti, 2018)

Masih dalam kawasan Simalem Resort, pada spot yang berbeda, identitas bentukan Geriten sebagai unsur pembentuk identitas tempat, diperkuat dengan adanya pengulangan Geriten berskala kecil yang sederet dengan dua Geriten utama berskala besar, yang berada pada roof top bangunan utama, hotel.

Penerapan atap Geriten yang berulang ini secara tidak langsung mengundang hasrat pengunjung untuk berfoto di spot ini (selfie occasion), menjadikan kawasan ini sebagai simbol jati diri arsitektur Karo terkini.

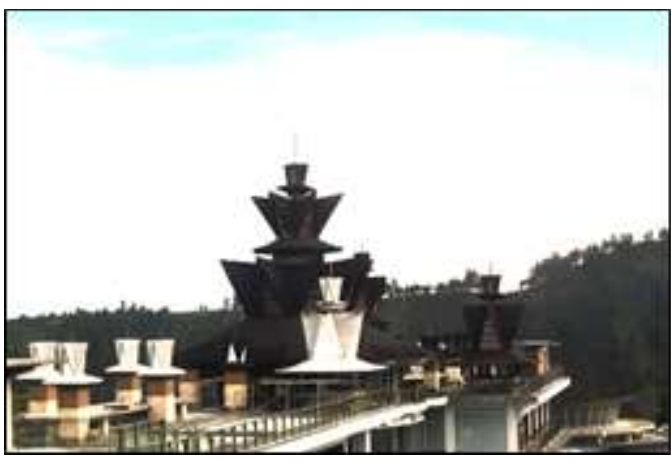

Gambar 12. Perulangan bentukan Geriten pada bangunan utama kawasan Simalem Resort, Kabupaten Karo (Sumber: observasi peneliti, 2018)

Penerapan focal point pada area duduk di taman juga dilakukan, dengan menerapkan bentukan Geriten pada taman.

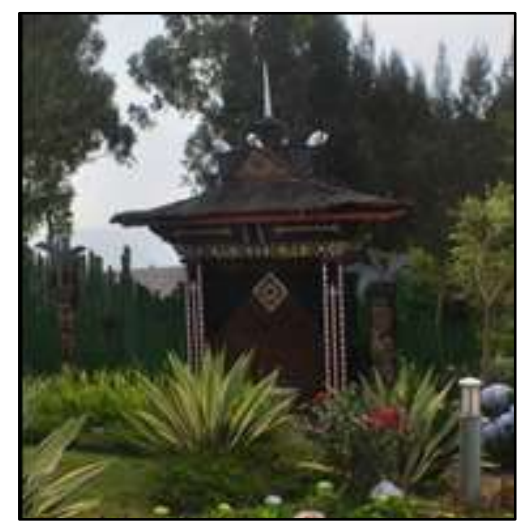

Gambar 13. Bentukan Geriten pada taman di kawasan Simalem Resort, Kabupaten Karo

(Sumber: observasi peneliti, 2018)

Aplikasi bentukan Geriten di kota Medan didapati dari bangunan Jambur, yang berfungsi sebagai ruang serba guna khas masyarakat Suku Karo. Keberadaan bangunan jambur tidak berdinding dan berpanggung dan secara umum digunakan sebagai tempat pelaksanaan pesta-pesta adat Karo, baik pesta adat pernikahan maupun pesta adat kematian.

Pada jambur Tamsaka di Kota Medan, Geriten terdapat pada area gapura masuk, yang dilakukan dengan perulangan paralel pada bagian ayo. Perulangan yang dilakukan merupakan sebuah tipologi baru, yang tidak terlihat pada kawasan Kabupaten Karo secara umum. 


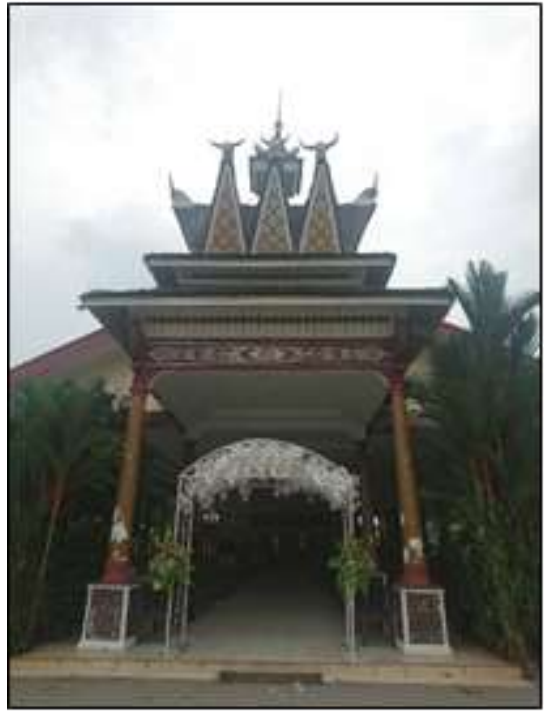

Gambar 14. Bentukan Geriten pada gapura, dengan perulangan ayo pada Jambur Tamsaka, Kota Medan (Sumber: observasi peneliti, 2018)

Bangunan lain di Kota Medan yang dijadikan objek penelitian adalah bangunan Anjungan Kabupaten Karo di dalam kawasan Pekan Raya Sumatera Utara (PRSU), Kota Medan. Fungsi dan aktivitas pada bangunan ini adalah memperkenalkan kepada masyarakat tentang budaya Karo. Bangunan ini sudah bergaya modern, adapun unsur karo hanya terdapat pada bagian atap dan ornamen saja. Bentukan Geriten yang didapati pada bagian entrance bangunan diharapkan jadi penanda dan pembentuk identitas pada bangunan ini.

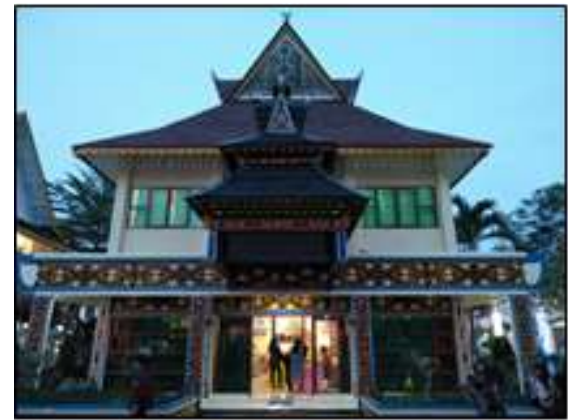

Gambar 15. Bentukan Geriten pada entrance Anjungan Kabupaten Karo, PRSU, Kota Medan

(Sumber: observasi peneliti, 2018)

Pada kawasan PRSU ini, juga terdapat satu penerapan bentukan geritan yang diharapkan sebagai pembentuk identitas tempat. Tugu PRSU, yang berada pada bagian paling depan kawasan ini, menjulang tinggi, mengungkap unsur vertikalitas secara nyata, agar menjadi landmark pada Kota Medan dan menjadi penanda arah saat acara PRSU dilaksanakan.

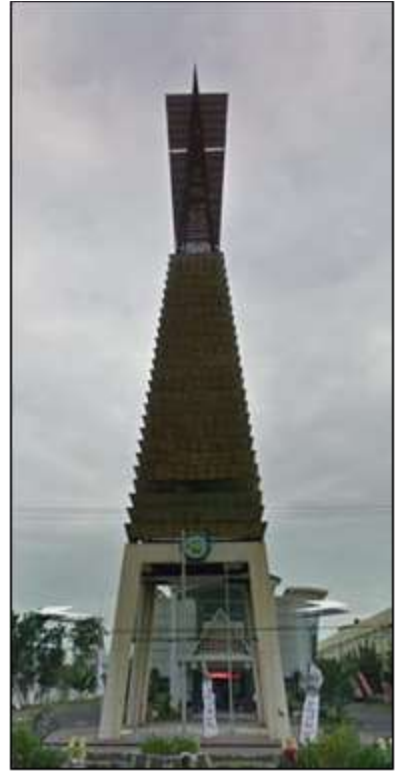

Gambar 16. Bentukan Geriten pada Tugu PRSU, Kota Medan (Sumber: Google Maps, 2018)

Secara keseluruhan bentukan atap Geriten yang dipakai pada arsitektur meng-kini dengan stilisasi dalam ukuran dan proporsi merupakan bentukan arsitektur yang diminati sebagai penanda tempat (landmark) dengan pencapaian tatanan rhythm perulangan, olahan vista, peninggian letak, ungkapan focal point.

Transformasi makna oleh pemakaian bentukan Geriten antara lain dimaksudkan sebagai virtual boundary, pencapaian suasana enclosure, pembeda wilayah, kekuasaan, tempat (distinctiveness) dan simbol pengukuhan kesamaan (kekuasaan) yaitu similaritas korps pemerintah.

\section{KESIMPULAN}

Arsitektur Geriten Karo dalam pemanfaatannya sebagai elemen tampang arsitektural bagi kreasi desain arsitektur meng-kini di Kabupaten Karo menunjukkan kecenderungan sebagai unsur artifisial bentuk berupa penguatan pembentukan landmark (penanda tempat) melalui olahan tatanan rhythm perulangan, olahan vista, peninggian letak, ungkapan focal point.

Bentuk ayo dengan tampang empat muka mampu tampil sebagai pembentuk identitas Karo yang kuat dalam transformasi bentuk dan proporsi yang beragam namun tetap dapat menampilkan nuansa ke-Karo-an yang kental.

Unsur bentuk atap Geriten dengan keragaman variasinya pantas dilestarikan dan dikuatkan 
sebagai unsur arsitektur pembentuk identitas tempat yang berjati diri.

\section{UCAPAN TERIMA KASIH}

Terima kasih kepada Lembaga Penelitian Universitas Sumatera Utara atas pendanaan penelitian ini dengan judul Analisis Arsitektur Geriten Karo Sebagai Faktor pembentuk Identitas Tempat, sesuai dengan Kontrak Pelaksanaan Penelitian TALENTA Universitas Sumatera Utara Tahun Anggaran 2018 Nomor : 2590/UN5.1.R/PPM/2018 Tanggal 16 Maret 2018, Penelitian Dasar.

\section{DAFTAR PUSTAKA}

Barliana, M. S., \& Cahyani, D. (2011). Arsitektur, kekuasaan, dan nasionalitas. Kerjasama Metatekstur dengan Laboratorium Sejarah Arsitektur, Kota \& Budaya Bermukim, Jurusan Pendidikan Arsitektur, Universitas Pendidikan Indonesia.

Clayton, S. (2003). Environmental identity: A conceptual and an operational definition (Identity a).

Creswell, J. (2017). Research design: Qualitative, quantitative, and mixed methods approaches. Sage Publications.

Dunham-Jones, E. (2008). Retrofitting suburbia: urban design solutions for redesigning suburbs. John Wiley \& Sons.

Fried, M. (2000). Continuities and discontinuities of place. Journal of Environmental Psychology, 20, 193-205.

Hidalgo, M. C., \& Herna'ndez, B. (2001). Place attachment: conceptual and empirical questions. Journal of Environmental Psychology, 21, 273-281.

Lalli, M. (1992). Urban-related identity: theory, measurement and empirical findings. Journal of Environmental Psychology, 12, 285-303.

Lindarto, D. (2018). Kearifan Lokal Modifikasi Potensi Place Identity Geriten Karo. Seminar Local Wisdom Proceeding USU.

Loebis, M. N. (2004). Raibnya Para Dewa: Kajian Arsitektur Karo. Medan: Bina Teknik Press.

Lynch, K. (1960). The image of the city. USA: MIT press Cambridge.

Manzo, L. C. (2003). Beyond house and haven: toward a revisioning of emotional relationships with places. Journal of Environmental Psychology, 23, 47-61.

Manzo, L. C. (2005). For better or worse: exploring multiple dimensions of place meaning. Journal of Environmental Psychology, 25, 67-86.
Prijotomo, J. dkk. (2004). Arsitektur Nusantara: menuju keniscayaan. Wastu Lanas Grafika.

Rapoport, A. (1969). House Form and Culture. New York: Prentice-Hall, Inc.

Riger, S., \& Lavrakas, P. J. (1981). Community ties: patterns of attachment and social interaction in urban neighborhoods. American Journal of Community Psychology, 9, 55-66.

Scannel, L. et al. (2009). Defining place attachment: A tripartite organizing framework. Journal of Environmental Psychology, 30, 1-10.

Schefold, R, et al. (2014). Survey of Vernacular Architecture in Western Indonesia. Indonesian Houses Vol.2.

Schulz, C. N. (1980). Genius loci. New York: Rizzoli.

Stedman, R. (2003). Is it really just a social construction? The contribution of the physical environment to sense of place. Society and Natural Resources, 16, 671685.

Sulistijowati, M. (2017). Struktur di Arsitektur Nusantara. Prosiding Temu IImiah IPLBI, 19-24.

Twigger-Ross, C. L., \& Uzzell, D. L. (1996). Place and identity processes. Journal of Environmental Psychology, 16, 20152220. 